\title{
Foreign Interest Rate, Monetary Policy and Bank Credit
}

\section{Taufiq Carnegie Dawood}

Faculty of Economics and Business, Syiah Kuala University, Banda Aceh, Indonesia Corresponding Author: taufiq.dawood@unsyiah.ac.id

Recieved: July 2017 | Revised: May 2017 | Accepted: October 2018

\begin{abstract}
This paper adds to the body of knowledge by providing a data based proof on the effect of foreign interest rate and monetary policy on credit to the private sector provided by domestic banks in developing countries. This subject matter is significant for a developing economy due to the fact that about 79 percent of total credit to the private sector in these set of countries are provisioned through credits by banks, therefore its movements have important effects on the stability of the financial system. Using the Structural Vector Autoregressive method, this paper found that domestic credit provided by banks in home country is affected by interest rates from abroad. Furthermore the effect of foreign rates of interest on credit depends on the intensity of the foreign rates of interest shocks towards income side in contrast to cost from interest in the balance sheet of banks of the home country. Conversely, a monetary contraction reduces the amount of credit provision by bank, with a delayed response (lag). In addition, both monetary policy of home country and interest rate of abroad gives important effect on the provision of domestic credit.
\end{abstract}

Keywords: Monetary policy, foreign interest rate, bank credit, developing countries, SVAR JEL classification: E51, E52, E47, F65, G21

How to Cite: Dawood, T. (2018). Foreign Interest Rate, Monetary Policy and Bank Credit. Jurnal Ekonomi Pembangunan: Kajian Masalah Ekonomi dan Pembangunan, 19(2). doi:https://doi. org/10.23917/jep.v19i2.5244

DOI: https://doi.org/10.23917/jep.v19i2.5244

\section{Introduction}

Financial stability is an important element in the development of a country, and the global financial crisis has shown the key role of financial intermediation in the stability of an economy, and in policy making. Reinhart \& Rogoff (2008) argued that the newly set up and unregulated or lightly regulated financial entities such as the Sub Prime Mortgage market in the United States before the wake of the 2008 global crises had increased vulnerability of the United States financial system and intermediation, which resulted into the crises. Using a UK Bank as an example, (Shin, 2009) argued that vulnerability in financial intermediation system stemming from institutional investor reliance on short term financing has resulted it being prone to negative external financial shocks. The Mortgage back securities debacle in The United States has resulted in the wake of de-leveraging of the UK and global credit markets, disturbed financial intermediation and resulted in the global financial crisis of 2008. Claessens, Dell'Ariccia, Igan, \& Laeven (2010) argued that new more sophisticated financial intermediaries and instruments and household debts coupled with flaws with policy framework and weak supervision of the state of health of the intermediation system were at the 
heart of the global financial crises. In addition this paper argued that although monetary policy and micro-prudential policies are necessary but they are not sufficient in safeguarding the economy from shocks which may have detrimental effects to the economy. Furthermore Blanchard, Dell'Ariccia, and Mauro (2010) argued that financial intermediation regulation cannot be left outside the core macroeconomic policy framework because a stalled financial intermediary system have detrimental effects on the real economy as shown from the global financial crisis. Adrian and Song Shin (2010) argued that financial intermediaries is the engine of the financial cycle. The financial cycle in turn is at the heart of the risk taking channel of monetary policy transmission mechanism. And Rey (2016) argued that the global financial crisis has underlined the importance of financial frictions on the monetary policy transmission mechanism (in particular the international transmission mechanism of monetary policy), and financial stability. This paper also underlines the importance of financial stability for macroeconomic soundness'.

In developing nations, financial intermediation, especially the banking sector, plays a more prominent role in the provision of financing than other financial sectors such as the capital market or the bonds market. Based on The Bank for International Settlement's data, on average, a proportion of 79 percent of financing to the private non-financial sector was provided by the banking sector in developing countries in the second quarter of 2017. Whereas, the average percentage of financing channelled by the banking sector in developed countries which is about 55 percent. (See Tables A1 and A2 in the Appendix). This fact underlines the importance of bank credits for developing countries in general, and for a developing country such as Indonesia in particular.

Topics on the relationship between bank credit and monetary policy has been discussed in length in the literature. For some recent examples see (Altunbas, Gambacorta, \& Marques-Ibanez, 2010) as perceived by financial market investors, need to be considered, together with the other indicators (i.e., size, liquidity and capitalization, (Jiménez, Ongena, Peydró, \& Saurina, 2012), (Bruno \& Shin, 2015), (Cúrdia \& Woodford, 2016). A pioneering paper on this topic is (Bernanke \& Blinder, 1992). This which empirically studied the influence of monetary policy on bank credit for the United States, concluded that a rise on the Federal funds rate resulted in a fall of bank credit, but with a lag. An extension of this work was conducted by Vera (2012), by including more recent data points. Vera (2012) obtained similar conclusions but the impact of monetary policy on credit has far fallen over the period. This set of literature concludes that a rise of the monetary policy rate resulted in a fall of bank credit, but with a lag.

Globalization has made funds to flow in and out relatively freely to and from countries. Due to this development, foreign interest rates may influence economic conditions in developing countries. This serves as a challenge for monetary policy making for central banks and monetary authorities of developing economies as argued by the following scholars. di Giovanni and Shambaugh (2008) found that high foreign interest rates results in contraction of the real GDP of the domestic economy. This contractionary effect of foreign interest rates on real GDP only exist in countries with a fixed exchange rate regime. This serves as a challenge for monetary policy making because maintaining the real output gap is one of the objective of monetary policy. Aizenman and Glick (2009) found that sterilization was widely conducted in Asia and Latin America due to worries of hiking inflationary impact of inflows of foreign reserves. Mishkin (2009) argued that globalization did not lead to the decline of the impact of monetary policy stance changes on inflation and domestic output gaps. Furthermore this paper found that foreign monetary policy (through foreign output gap) did not have an important impact on domestic inflation and thus did don't have the role of demising the potency of domestic monetary policy in fighting inflation. In addition this paper argued that domestic monetary 
policy have sufficient power in controlling domestic interest rate, which is used as the main instrument for controlling domestic inflation and output gap. Bruno \& Shin (2015) found that a contraction of the monetary policy stance of the United States results in a decrease in a decrease of international banks' cross-country capital flows. This paper argued that this factor partially explains the flow of capital from developed countries to developing countries in the 1990-s. In addition (Ghosh, Ostry, \& Chamon, 2016) documenting that indeed both instruments tend to be deployed. We show that whether discretionary monetary policy or inflation targeting is preferable depends on the volatility of shocks relative to the central bank's time inconsistency problem. The use of FX intervention as a second instrument improves welfare under both regimes, but more so under inflation targeting. Overall, a regime of (two-way that in an economy affected by globalization, the optimal policy response of a developing country in their attempt to tame inflation and weaken the negative affect of an exchange rate disequilibrium is to use a combination of monetary policy and exchange rate interventions.

Despite the importance of foreign interest rates may have on an economy, discussions on the effect of foreign interest rates changes on domestic bank credit in the literature is still very limited. One study which focus on the relationship of foreign interest rate and exchange rate on domestic bank credit is (Zanforlin, 2011). This paper studied the relationship between cross country interest rates differentials (in this paper it is also termed as foreign funding cost), real exchange rate and domestic bank credit to the private sector by employing a panel of annual data of 91 countries from the span of 1970 to 2001. This study concluded that there is a negative relationship between foreign funding cost and bank credit, while the real exchange rate is positively related with domestic bank credit.

Notwithstanding the importance of the banking sector for the financial landscape of a developing economy, and findings on the effect of monetary policy on domestic bank credit, and findings on the effect of foreign interest rates on credit provided by banks, there does not exists a study which analyse empirically the effect of foreign interest rates shocks together with monetary policy shocks on domestic bank credit to the private sector in a cross country analysis of developing countries. Thus the current study endeavours to fill this gap in the literature by providing a cross country empirical analysis on the effect of foreign interest rates and monetary policy on domestic private sector credit from domestic banks in developing economies.

\subsection{Literature Review}

The following section provides literature review on the mechanism on how monetary policy affects bank credit, and also how foreign rates of interest affects domestic bank credit. The effect of monetary policy on bank credit are categorized into three arguments. The three arguments presented in this sections are the balance sheets channel and the bank lending channel and the risk taking channel. While the mechanism of the effect of foreign interest rates on domestic bank credit uses a modified version of the argument of the risk taking channel of monetary policy transmission mechanism. The first argument presented in the literature review is the balance sheet channel.

\subsubsection{Balance Sheet Channel}

The balance sheet channel argument was pioneered by (Bernanke, Gertler, \& Gilchrist, 1999). This model has been applied and extended in numerous angles. An example of these extensions is (Angelopoulou \& Gibson, 2009). This paper found evidence of the balance sheet channel of monetary policy transmission mechanism in The United Kingdom. In addition (Chami \& Cosimano, 2010) found that the effect of monetary on bank credit with existence of the Basel Accord risk-based capital requirements, is evident and worked through the balance sheet channel. (Aysun \& Hepp, 2011) found that balance sheet channel transmission mechanism of monetary 
policy is stronger when the assets of the banks' are securitized. Delli et al. (2010) shown that the balance sheet channel can operate with an element of networking of credit. While (Dedola \& Lombardo, 2012) found that exposure of foreign countries through a balanced sheet which are interconnected provided a strong source of propagation mechanism of producing asymmetric shocks across economies.

In sum the balance sheet channel argues that a monetary policy contraction would increase the domestic rate of interest. Rate of interest rise causes a decrease the market value of balance sheet of firms. The motivation behind this outcome is due to negative relation concerning bond market value and its rate of return (Mishkin, 2013) . Rate of interest rise would reduce bonds market value, hence diminishes firm's balance sheet's market value.

\subsubsection{Bank Lending Channel}

This argument was proposed by (Bernanke \& Blinder, 1992). Just like the balance sheet channel, there are various applications and extensions of the bank lending channel. An example of application of the bank lending channel is (Matousek \& Sarantis, 2009). This paper found empirical evidence of the bank lending channel monetary policy transmission mechanism in eight Central and Eastern European Countries which are members of the European Union. This paper also found that the strength of the bank lending varies among countries and depends on the size and liquidity of the banks. While (de Mello \& Pisu, 2010) found empirical evidence of the bank credit channel monetary policy transmission mechanism in Brazil. While (Disyatat, 2011), using a dynamic stochastic general equilibrium model, found that the effect of the bank lending channel monetary policy transmission mechanism is weaker or stronger depending on the state of health of the banking sector. In addition this analysis found that the importance of the bank lending channel is enhanced with the greater reliance on market- based funding and in a well-developed financial system.

In sum, the discussion of the bank lending channel is the following. A monetary contraction raises domestic interest rates, which reduces bank's balance sheets values used for reserves. This would induce banks to decrease new and existing credit provision to firms. Ultimately this results in reduction of bank credit, but with a lag. In sum this arguments stipulates that a monetary contraction results in a fall in bank credit but with a lag.

\subsubsection{The Risk Taking Channel}

The last discussion of theory on how monetary policy affects bank credit is the Risk Taking Channel argued by (Adrian \& Song Shin, 2010) . (Borio \& Zhu, 2012) found that alterations and innovations in the financial system and prudential rules had raised the significance of the risk taking channel of monetary policy transmission mechanism. This paper also argued that the increased in prominence of the risk taking channel has the possibility of increasing the likelihood of the occurrence of business cycle fluctuation which may have detrimental effects towards the economy. (Angeloni, Faia, \& Lo Duca, 2015)to rationalize this evidence we build a macroeconomic model where banks subject to runs endogenously choose their funding structure (deposits vs. capital shown the existence of the risk taking channel of monetary policy transmission mechanism. This paper found that an expansionary monetary stance enhances the risk and the leverage of domestic banks. Furthermore, the monetary expansion resulted in banks taking higher risk, and the possibility of surges of the volatility of asset prices. While using confidential data of internal ratings of banks on businesses loans (Dell'ariccia, Laeven, \& Suarez, 2017) found empirical evidence of the risk taking channel of monetary policy transmission mechanism in the banking system of the United States. The found a negative relationship between short-term interest rates and the degree of risk 
taking (and thus the amount of bank credit).

In their argument, Adrian and Shin (2010), used the concepts Net Interest Margin and term spread. Net Interest Margin (NIM) is total interest income on the bank's balance sheet asset side minus the interest expense on the liabilities side. It governs profitability of total bank lending, present value of bank's income and capital. While term spread is the determinant of profitability of credit to the private non-financial sector, on the margin added to bank's the balance sheet, which in turn affects future NIM.

\subsection{Domestic Bank Credit and Foreign Interest Rate}

In discussing the impact of foreign interest rates on quantity of bank credit, I employ a modified version of the Risk Taking Channel discussed earlier. The discussion is as follows. Assume that the banking system in the small open developing economy holds foreign assets in their balance sheet. Assume also that they take foreign borrowing. Suppose due to some external shock results in foreign interest rates to increase. Following the discussion of the Risk Taking Channel, I argue that if the increase causes the total interest income to fall short of total interest cost in bank's balance sheet. In turn this cause NIM to fall, which ultimately result in a fall of the size of domestic bank credit provision to the private sector. On the other hand suppose the rise in foreign interest rates instead augments total interest income by more than total interest cost in bank's balance sheet. This would augment NIM and thus ultimately the sum of domestic bank credits expands.

\section{Research Methods}

This paper employs the Structural Vector Autoregressive model (SVAR). The SVAR model consists of eight variables which can be specified in the following vector.

$$
\mathbf{Y}_{t}^{\prime}=\left(o p w_{i}, r f_{i}, i p_{i}, c p i_{i}, \mathrm{ml}_{t}, \mathrm{rdom}_{i}, e r_{i}, c r_{t}\right)
$$

The first three variables in the vector above are $o p w_{t}$ which denotes world oil prices, $r f_{t}$ denotes the Federal Funds rate (which I use as to represent rates of interest of foreign) and $i p_{t}$ denotes industrial production correspondingly. The next three variables in the above vector are consumer price index $c p i_{t}$, base money $m 1_{t}$ and domestic short term interest rates rdom $_{t}$ respectively. While the remaining two variables in the aforementioned vector are the nominal exchange rate denoted as $e r_{t}$, and credit provision by banks to the non-financial private sector denoted as $\mathrm{Cr}_{t}$ correspondingly.

In general, the model in structural form with $p$ number of lags can be written as the following.

$C_{0} Y_{T}=k+C_{1} Y_{t-1}+C 2 Y_{t-2}+\ldots+C P Y_{t-p}+V_{t}$

Denoting $Y_{t}$ as an (n $\left.\times 1\right)$ vector, $k$ is a (n $\left.\mathrm{x} 1\right)$ vector of constants, $V_{t}$ is an (n x 1 ) vector of structural shocks. The structural shocks $V_{t}$ are serially and mutually uncorrelated. The contemporaneous matrix $C_{0}$ is be defined as the following.

$$
\mathbf{C}_{0}=\left(\begin{array}{cccc}
1 & -c_{12}^{(0)} & \cdots & -c_{1 n}^{(0)} \\
\vdots & \vdots & \cdots & \vdots \\
\vdots & \vdots & \cdots & \vdots \\
-c_{n 1}^{(0)} & -c_{n 1}^{(0)} & \cdots & 1
\end{array}\right)
$$

Whereas the matrix $\mathrm{C}_{\mathrm{s}}$ is a matrix of dimension ( $\mathrm{n} \times \mathrm{n}$ ) which the row $k$ and column $l$ element of the matrix is $C_{k l}^{(r)}$ for $r=1,2, \ldots, p$.

Given the existence of the inverse matrix $\mathbf{C}_{0}^{-1}$, the above structural model can be modified by pre-multiplying equation (2) above to get the following result.

$$
\mathbf{Y}_{\mathrm{t}}=\mathbf{C}_{\mathrm{v}}^{-1} \mathbf{k}+\mathbf{C}_{0}^{-1} \mathbf{C}_{1} \mathbf{Y}_{\mathrm{t}-1}+\mathbf{C}_{\mathrm{0}}^{-1} \mathbf{C}_{2} \mathbf{Y}_{\mathrm{t}-2}+\ldots+\mathbf{C}_{0}^{-1} \mathbf{C}_{\mathrm{p}} \mathbf{Y}_{\mathrm{t}-\mathrm{p}}+\mathbf{C}_{0}^{-1} \mathbf{v}_{\mathrm{t}}(4)
$$

Rewrite equation (4) into the following form.

$$
\mathbf{Y}_{\mathrm{t}}=\mathbf{d}_{\mathrm{t}}+\boldsymbol{\varphi}_{1} \mathbf{Y}_{\mathrm{t}-1}+\boldsymbol{\varphi}_{2} \mathbf{Y}_{\mathrm{t} \cdot \mathrm{2}}+\ldots+\boldsymbol{\varphi}_{\mathrm{p}} \mathbf{Y}_{\mathrm{t}-\mathrm{p}}+\mathbf{e}_{\mathrm{t}}
$$

where the above matrix/vectors are defined as the 
following.

\section{$\mathbf{d}_{0}=\mathbf{C}_{0}^{-1} \mathbf{k}$}

$\boldsymbol{\varphi}_{\mathrm{i}}=\mathbf{C}_{n}^{-1} \mathbf{C}_{\mathrm{j}}$ $\mathbf{e}_{\mathrm{t}}=\mathbf{C}_{n}^{-1} \mathbf{v}_{\mathrm{t}}$

for $\mathrm{j}=1,2, \ldots \mathrm{p}$.

Equation 4 is the structural dynamic model, while equation 5 is the structural model in reduced form and the vector $e_{t}$ are reduced form residuals. The relationship between the structural shocks and the reduced form residuals can be written in the following equation.

$\mathrm{V}_{\mathrm{t}}=\mathrm{C}_{0} \mathrm{e}_{\mathrm{t}}$

Equation 9 implies, identification of the structural shocks is dependent on the contemporaneous matrix $c_{0}$. In identifying the structural shocks, I employ the strategy from literature (see Kim and Roubini (2000)) and extend it to include domestic credit. The strategy for identifying the shocks is presented in the following matrix.

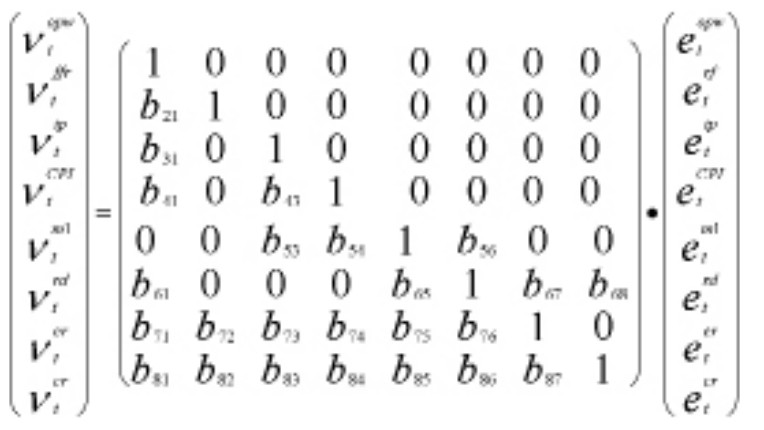

The countries used in this study is based on availability of data. The data used in this study are of monthly frequency for India from June 1997 to September 2015, Mexico from January 1997 to September 2015, Chile from January 1998 to October 2015, South Africa from January 1986 to November 2015 and Turkey from February 2002 to November 2015. These data are obtained from the OECD data base except for data on domestic bank credit which was acquired from the central banks of each country. Using the Akaike Information Criterion (Doan, 2013), 13 lags is found to be appropriate for the above model.

\section{Results and Discussion}

In analysing the response of bank credit due to shocks to monetary policy and foreign interest I employ Impulse Response Analysis functions. In examining the Impulse Response functions F I use the Bayesian Monte Carlo Integration approach in RATS statistical package. Using 90 percent confidence bands, this package draws 10,000 replications by using the Random Walk Metropolis Hastings method (see Doan (2013).

The IRF analysis for a one percent rise in foreign interest rates (denoted as rf), is depicted in figures 1 to 6 in the appendix, and the discussion is as follows. This shock results in a one percent increase of the country's private non-financial sectors' provision of domestic bank credit. Whereas its response is 0.6 percent and 0.5 percent for Colombia and India respectively. And in Turkey, and South Africa bank credit also rose although not significant. (see figures 1 to 5 in the appendix)

The reason for the above results follows from the Risk taking channel argument. Following the argument of Adrian \& Shin (2010). The argument on how foreign interest rates affects bank credit using the risk taking channel is as follows. Given that the banking system in a small open developing economy holds foreign assets in their balance sheet. Assume also that they take foreign borrowing. Suppose due to some external shock results in foreign interest rates to increase. Following the discussion of the Risk Taking Channel, if the rise in foreign interest rates causes total interest income to increase by more than the rise of total interest cost in bank's balance sheet, this cause the Nett Interest Margin of supplying new credit by the bank to rise. Ultimately the rise in foreign interest rate would result in a rise of the size of domestic bank credit provision to the private sector. Given that firm s are financially constrained, this results in an increase in domestic bank credit.

In addition, given that firms have sufficient 
time to adjust their balance sheet, I argue that this result is partially also be due to banks and firms having sufficient time to adjust and substitute away from the more costly foreign credit to domestic bank credit. The combination of the increased supply of domestic bank credit by domestic banks plus the increase in demand of domestic credit by domestic firm resulted in the increase of domestic bank credit in the economy.

On the other hand, the one percent increase in foreign interest rates in Chile caused the quantity of credit to fall. The reason for this case is that the rise in foreign interest rates increased total interest income but by less than total interest cost in bank's balance sheet. This would decrease NIM and ultimately reduce the sum of domestic bank credit (see figure 6 at the appendix)

The reason for the above result is consistent with the results found by (Bruno \& Shin, 2015). In that paper it is found that a contraction of the monetary policy stance of large foreign country resulted in a decrease in the flows foreign capital channelled by international banks' to domestic banks of the developing country. The reduction of the foreign capital inflow in turn would have an impact of reducing funds available for domestic banks of the developing country that can be used for lending. Ultimately the monetary contraction of the central bank of the large foreign country would decrease the amount of domestic credit in the developing country. As a note Bruno and Shin (2015) had shown that this mechanism on how foreign interest rates affects domestic bank credit, explains partially the flow of capital from developed countries to developing countries in the 1990-s. Furthermore result finding of the decline of domestic bank credit due to the rise of the foreign interest rate is also in line with result found by (Zanforlin, 2011). This paper found that an increase in foreign interest rates results in an increase in foreign funding cost. In turn the increase in foreign funding cost results in a fall of the source of funding for domestic banks which can be channelled to domestic borrowers. In the end the rise in foreign interest rate would result in a fall of domestic bank credit.

For the Impulse Response Analysis of monetary policy shocks, a monetary tightening which result a one percent rise of interest rate of the home economy. For the countries in the study, the Impulse response Functions shows that the rise in home interest rate causes the sum of bank credit to decline, but with a lag. However, the fall of domestic bank credit due to a monetary contraction is only significant for Mexico (see figure 7 of the appendix). For India, Chile, Turkey, Colombia and South Africa, a monetary contraction results is a fall in domestic bank credit, but it is not statistically significant.

This fall in domestic bank credit due to a monetary policy contraction is in line with the conclusion found by bank lending channel monetary policy transmission mechanism put forward by Bernanke and Blinder (1992) and verified by (Vera, 2012), although this paper showed that the impact of the bank credit monetary policy transmission mechanism has weakened as compared to the 1990s.

The non-significance of the effect of monetary policy on domestic bank credit as shown from the Impulse Response Function graphs for India, Chile, Turkey, Colombia and South Africa indicates that monetary policy is less appropriate tool in manage the growth of bank credit in Indonesia to safeguard the health and soundness of the financial system.

In addition to Impulse Response Analysis, this study also employs analyses the Forecast Variance Error Decomposition. The Forecast Variance Error Decomposition measures the proportion of variation of an endogenous variable in the model due to various shocks included in the model. In sum, the magnitude of the Forecast Variance Error Decompositions provide measurement of the strength of the influence of each shocks on the corresponding endogenous variable in the model (Barnett, Bhadury, \& Ghosh, 2016).

Table 1. Forecast Variance Error 
Decomposition analysis in Chile and Colombia

\begin{tabular}{ccccccc}
\hline \multirow{2}{*}{ Months } & \multicolumn{3}{c}{ Chile } & \multicolumn{3}{c}{ Colombia } \\
\cline { 2 - 7 } & standard error & rf & rdom & standard error & rf & rdom \\
\hline 1 & 0.825 & 3.226 & 2.041 & 0.507 & 3.454 & 1.949 \\
3 & 1.377 & 8.769 & 0.958 & 1.042 & 6.759 & 1.322 \\
4 & 1.553 & 8.155 & 0.893 & 1.3 & 8.684 & 1.444 \\
6 & 1.844 & 9.846 & 0.696 & 1.856 & 14.523 & 0.799 \\
12 & 2.751 & 6.983 & 1.986 & 3.171 & 16.866 & 1.618 \\
24 & 4.171 & 4.195 & 1.101 & 5.451 & 11.356 & 0.806 \\
48 & 7.22 & 6.964 & 1.979 & 9.69 & 5.759 & 6.585 \\
72 & 13.936 & 16.1 & 6.846 & 16.447 & 10.406 & 3.329 \\
\hline \multicolumn{7}{c}{ Source: RATS output } \\
\end{tabular}

Table 2. Forecast Variance Error Decomposition analysis in Turkey and India

\begin{tabular}{ccccccc}
\hline \multirow{2}{*}{ Months } & \multicolumn{3}{c}{ Turkey } & \multicolumn{3}{c}{ India } \\
\cline { 2 - 7 } & standard error & rf & rdom & standard error & rf & rdom \\
\hline 1 & 0.651 & 5.137 & 0.099 & 1.023 & 0.015 & 10.055 \\
3 & 1.106 & 3.132 & 0.336 & 1.589 & 1.318 & 8.471 \\
4 & 1.355 & 2.698 & 0.241 & 1.784 & 3.512 & 6.966 \\
6 & 1.798 & 1.554 & 0.171 & 2.098 & 8.577 & 5.154 \\
12 & 2.879 & 6.576 & 3.694 & 2.886 & 11.703 & 3.419 \\
24 & 4.119 & 7.338 & 6.049 & 4.385 & 11.725 & 2.402 \\
48 & 5.913 & 6.664 & 11.002 & 6.484 & 5.894 & 3.650 \\
72 & 7.041 & 5.8 & 9.862 & 8.211 & 3.865 & 2.867 \\
\hline
\end{tabular}

Table 3. Forecast Variance Error Decomposition analysis in Mexico and South Africa

\begin{tabular}{ccccccc}
\hline \multirow{2}{*}{ Months } & \multicolumn{3}{c}{ Mexico } & \multicolumn{4}{c}{ South Africa } \\
\cline { 2 - 7 } & standard error & rf & rdom & standard error & rf & rdom \\
\hline 1 & 0.785 & 0.013 & 1.123 & 12.775 & 0.024 & 0.926 \\
3 & 1.269 & 0.875 & 6.766 & 13.656 & 0.888 & 0.95 \\
4 & 1.513 & 5.086 & 8.084 & 14.318 & 1.208 & 1.014 \\
6 & 1.93 & 10.07 & 6.09 & 14.652 & 1.221 & 1.827 \\
12 & 3.626 & 19.73 & 10.797 & 15.733 & 2.881 & 2.182 \\
24 & 7.255 & 29.561 & 15.599 & 17.73 & 5.609 & 3.59 \\
48 & 10.249 & 27.414 & 15.69 & 19.395 & 7.093 & 4.733 \\
72 & 11.583 & 22.282 & 20.023 & 19.928 & 7.302 & 5.076 \\
\hline
\end{tabular}

Source: RATS output

The information for the Forecast Variance Error Decomposition analysis was obtained from the research output and is presented in Tables 1 , 2 and 3 below. The first to notice of the results is that the percentage variation of monetary policy shocks on domestic bank credit is small in all countries, with the exception of India. On impact, the percentage variation of domestic bank credit due to the monetary policy shock is about 2 percent for Chile, less than 2 percent for Colombia and Mexico and is less than 1 percent for Turkey and South Africa. However, on impact, 
the percentage variation of domestic bank credit due to the monetary policy shock for India is a bit over 10 percent, but it subsequently fell. The magnitude of variation of monetary shocks on domestic bank credit for Chile, Colombia, Turkey, India and South Africa remains below four percent even after 12 months. This results indicates that monetary policy is not very potent instrument in influencing domestic bank credit. This result is in line with the finding of Vera (2012), in which this paper found that the strength of the bank lending channel had waned in the United States. Considering the results obtained from the estimation, a further question that can be posed is why has the monetary policy on domestic bank credit in developing countries had weakened? One answer that can offered for this question, is that it is due to financial development and financial innovations. Altunbas, Gambacorta and Marques-Ibanez (2010) found that financial innovations resulted in weaker influence of monetary policy on bank credit. As found by this paper, advancements in financial innovations (such as credit derivatives and securitizations of assets) enables banks to give out new loans and sell them in the financial market thus obtaining additional liquidity and relaxing constraints in the capital requirement in generating new loans.

In addition Tables 1 to 3 shows that foreign interest rates can influence on domestic bank credit, and its influence can be more important than monetary policy. As shown in Tables 1 to 3 above, the variation of bank credit to nonfinancial private sectors vis-à-vis monetary policy dominates foreign interest rates on the first month only in India, Mexico and South Africa. While for Chile, Colombia and Turkey the variation of bank credit to non-financial private sectors due to foreign interest rates is larger than monetary policy shocks. Yet after 6 months, for India and Mexico and after 12 months for South Africa, the variation of the Federal Funds rate surpass that of monetary policy of the domestic developing country. The reason for this result is that it may be due to the the result of increased globalization which makes many nations including developing countries to be more integrated the global financial market. This argument is in line with Claessens et al. (2010). In relation to this argument, Bruno \& Shin (2015) had shown that the impact of a change in monetary policy stance of the United States is transmitted globally and influences the flow of capital in other nations,

The last result above suggests that in addition to monetary policy, foreign interest rates also has an important influence on banks' credit in developing countries. This is a novel finding and contribution of the paper to the literature of economics; both monetary policy and foreign interest rates influences bank credit in developing countries. In addition the results indicates that monetary policy stance of central banks of developing countries influences bank credit only up to 6 or at most 12 months. After 12 months, foreign interest rates dominates. In addition from the impulse response functions it is shown that the impact of the change of the monetary policy stance of the central banks of developing countries does not significantly affect domestic bank credit in these countries. On the other hand the Impulse Response Analysis shows that foreign interest rates have a significant effect on bank credit. These results underlines that monetary policy is less effective as a tool to be used in managing the growth of bank credit. This result is in line with the finding by (Vera, 2012). Therefore monetary policy is not effective for nurturing the stability of the financial system of developing countries. To oversee the growth of bank credit, macroprudential policies should instead be used in the effort to maintain the soundness of Indonesia's financial landscape. In addition authorities in charge of macroprudential policies should take into account the effect of foreign interest rates and also financial innovation in formulating and implementing the policies.

\section{Conclusions}

Contributing to the relatively sparse literature on how monetary policy and foreign 
interest can influence bank credit. And by employing a structural VAR model on six developing countries, this paper concluded that domestic credit provided by banks in home country is affected by interest rates from abroad. And its effect on credit depends on the intensity of the foreign shock's influence towards income in contrast to cost from interest in the balance sheet of banks of the home country. Conversely, a monetary contraction reduces the amount of credit provision by bank, with a delayed response. However monetary policy has no significant effect on domestic bank credit. These novel findings of the paper underlines that monetary policy is less effective as a tool in managing credit growth. Other policies such as macroprudential polices should instead be used in the effort to guard the stability of the financial system of developing countries. Furthermore, in formulating and conducting macroprudential policies, the central banks of developing countries should take into account the effect of foreign interest rates on domestic bank credit. And both monetary policy of home country and interest rate of abroad gives important effect on the provision of domestic credit. This result provides support to the argument that conventional monetary policy have limited ability to manage credit growth and promote financial stability.

\section{Acknowledgement}

I would like to thank Dr. John Nana Francois of West Texas A\&M University, Canyon, Texas USA for the valuable discussions and inputs. I would also like to thank two anonymous referees for their inputs which greatly improved the paper.

\section{References}

Adrian, T., \& Song Shin, H. (2010). Financial intermediaries and monetary economics. Handbook of Monetary Economics (Vol. 3). https://doi.org/10.1016/B978-0-444-532381.00012-0

Aizenman, J., \& Glick, R. (2009). Sterilization, monetary policy, and global financial integration. Review of International Economics, 17(4), 777-801. https://doi. org/10.1111/j.1467-9396.2009.00848.x

Altunbas, Y., Gambacorta, L., \& Marques-Ibanez, D. (2010). Bank risk and monetary policy. Journal of Financial Stability, 6(3), 121129. https://doi.org/10.1016/j.jfs.2009.07.001

Angeloni, I., Faia, E., \& Lo Duca, M. (2015). Monetary policy and risk taking. Journal of Economic Dynamics and Control, 52, 285-307. https://doi.org/10.1016/j. jedc.2014.12.001

Angelopoulou, E., \& Gibson, H. D. (2009). The balance sheet channel of monetary policy transmission: Evidence from the United Kingdom. Economica, 76(304), 675-703. https://doi.org/10.1111/j.14680335.2008.00710.x

Aysun, U., \& Hepp, R. (2011). Securitization and the balance sheet channel of monetary transmission. Journal of Banking and Finance, 35(8), 2111-2122. https://doi. org/10.1016/j.jbankfin.2011.01.011

Barnett, W. A., Bhadury, S. S., \& Ghosh, T. (2016). An SVAR Approach to Evaluation of Monetary Policy in India: Solution to the Exchange Rate Puzzles in an Open Economy. Open Economies Review, 27(5), 871-893. https://doi.org/10.1007/s11079-016-9403-2

Bernanke, B. S., \& Blinder, A. S. (1992). The federal funds rate and the channels of monetary transmission. American Economic Review, 82(4), 901-921. https://doi. org/10.2307/2117350

Bernanke, B. S., Gertler, M., \& Gilchrist, S. (1999). Chapter 21 The financial accelerator in a quantitative business cycle framework. Handbook of Macroeconomics. https://doi. org/10.1016/S1574-0048(99)10034-X

Blanchard, O., Dell'Ariccia, G., \& Mauro, P. (2010). Rethinking macroeconomic policy. Journal of Money, Credit and Banking, 42(SUPPL. 
1), 199-215. https://doi.org/10.1111/j.15384616.2010.00334.x

Borio, C., \& Zhu, H. (2012). Capital regulation, risk-taking and monetary policy: A missing link in the transmission mechanism? Journal of Financial Stability, 8(4), 236-251. https:// doi.org/10.1016/j.jfs.2011.12.003

Bruno, V., \& Shin, H. S. (2015). Capital flows and the risk-taking channel of monetary policy. Journal of Monetary Economics, 71, 119-132. https://doi.org/10.1016/j. jmoneco.2014.11.011

Chami, R., \& Cosimano, T. F. (2010). Monetary policy with a touch of Basel. Journal of Economics and Business, 62(3), 161-175. https://doi.org/10.1016/j. jeconbus.2009.12.001

Claessens, S., Dell'Ariccia, G., Igan, D., \& Laeven, L. (2010). Cross-country experiences and policy implications from the global financial crisis. Economic Policy, 25(62), 267-293. https://doi.org/10.1111/j.14680327.2010.00244.x

Cúrdia, V., \& Woodford, M. (2016). Credit Frictions and Optimal Monetary Policy. Journal of Monetary Economics, 84, 30-65. https://doi. org/10.1016/j.jmoneco.2016.10.003

de Mello, L., \& Pisu, M. (2010). The bank lending channel of monetary transmission in Brazil: A VECM approach. Quarterly Review of Economics and Finance, 50(1), 50-60. https:// doi.org/10.1016/j.qref.2009.09.006

Dedola, L., \& Lombardo, G. (2012). Financial frictions, financial integration and the international propagation of shocks. Economic Policy, 27(70), 319-359. https:// doi.org/10.1111/j.1468-0327.2012.00286.x

Dell'ariccia, G., Laeven, L., \& Suarez, G. A. (2017). Bank Leverage and Monetary Policy's RiskTaking Channel: Evidence from the United States. Journal of Finance, 72(2), 613-654. https://doi.org/10.1111/jofi.12467
Delli Gatti, D., Gallegati, M., Greenwald, B., Russo, A., \& Stiglitz, J. E. (2010). The financial accelerator in an evolving credit network. Journal of Economic Dynamics and Control, 34(9), 1627-1650. https://doi. org/10.1016/j.jedc.2010.06.019

di Giovanni, J., \& Shambaugh, J. C. (2008). The impact of foreign interest rates on the economy: The role of the exchange rate regime. Journal of International Economics, 74(2), 341-361. https://doi.org/10.1016/j. jinteco.2007.09.002

Disyatat, P. (2011). The bank lending channel revisited. Journal of Money, Credit and Banking, 43(4), 711-734. https://doi. org/10.1111/j.1538-4616.2011.00394.x

Doan, T. (2013). RATS manual: version 8.3. Evanston: Estima.

Ghosh, A. R., Ostry, J. D., \& Chamon, M. (2016). Two targets, two instruments: Monetary and exchange rate policies in emerging market economies. Journal of International Money and Finance, 60, 172-196. https://doi. org/10.1016/j.jimonfin.2015.03.005

Jiménez, G., Ongena, S., Peydró, J.-L., \& Saurina, J. (2014). Hazardous Times for Monetary Policy: What do 23 Million Loans Say About the Impact of Monetary Policy on Credit Risk-Taking? Econometrica, 82(2), 463-505. https://doi.org/10.3982/ECTA10104

Jiménez, G., Ongena, S., Peydró, J. L., \& Saurina, J. (2012). Credit supply and monetary policy: Identifying the bank balance-sheet channel with loan applications. American Economic Review, 102(5), 2301-2326. https://doi. org/10.1257/aer.102.5.2301

Matousek, R., \& Sarantis, N. (2009). The bank lending channel and monetary transmission in Central and Eastern European countries. Journal of Comparative Economics, 37(2), 321-334. https://doi.org/10.1016/j. jce.2008.09.008 
Mishkin, F. S. (2009). Globalization, macroeconomic performance, and monetary policy. In Journal of Money, Credit and Banking (Vol. 41, pp. 187-196). https://doi. org/10.1111/j.1538-4616.2008.00204.x

Mishkin, F. S. (2013). The Economics of Money, Banking, and Financial markets /. Pearson Publications Company. https://doi. org/10.1017/CBO9781107415324.004

Reinhart, C. M., \& Rogoff, K. S. (2008). Is the 2007 US sub-prime financial crisis so different? An international historical comparison. In American Economic Review (Vol. 98, pp. 339344). https://doi.org/10.1257/aer.98.2.339

Rey, H. (2016). International channels of transmission of monetary policy and the mundellian trilemma. IMF Economic Review. https://doi.org/10.1057/imfer.2016.4

Shin, H. S. (2009). Reflections on Northern Rock: The Bank Run that Heralded the Global Financial Crisis. Journal of Economic Perspectives, 23(1), 101-119. https://doi. org/10.1257/jep.23.1.101

Vera, D. (2012). How responsive are banks to monetary policy? Applied Economics, 44(18), 2335-2346. https://doi.org/10.1080/0003684 6.2011 .564143

Zanforlin, L. (2011). Domestic Lending when Financial Markets are Integrated: Is it all for Real. Applied Economics Letters, 18. 
Avalaible online at http://journals.ums.ac.id, Permalink/DOI: 10.23917/jep.v19i2.5244

Jurnal Ekonomi Pembangunan: Kajian Masalah Ekonomi dan Pembangunan, 19 (2), 2018, 138-155

\section{Appendixes.}

Table A1. Credit of Banking Sector to Total Financing in Developing Countries

\begin{tabular}{ccccccccc}
\hline \multirow{2}{*}{ Country } & \multicolumn{7}{c}{ Year/Quarter } & \\
\cline { 2 - 9 } & $\mathbf{2 0 1 1}$ & $\mathbf{2 0 1 2}$ & $\mathbf{2 0 1 3}$ & $\mathbf{2 0 1 4}$ & $\mathbf{2 0 1 5}$ & $\mathbf{2 0 1 6}$ & $\mathbf{Q 1 ~ 1 7}$ & $\mathbf{Q 2 ~ 1 7}$ \\
\hline Argentina & $75 \%$ & $78 \%$ & $78 \%$ & $79 \%$ & $76 \%$ & $75 \%$ & $75 \%$ & $75 \%$ \\
Brazil & $95 \%$ & $95 \%$ & $93 \%$ & $93 \%$ & $94 \%$ & $94 \%$ & $94 \%$ & $94 \%$ \\
China & $82 \%$ & $79 \%$ & $75 \%$ & $74 \%$ & $76 \%$ & $75 \%$ & $75 \%$ & $75 \%$ \\
Malaysia & $97 \%$ & $100 \%$ & $100 \%$ & $98 \%$ & $97 \%$ & $97 \%$ & $97 \%$ & $96 \%$ \\
Mexico & $47 \%$ & $48 \%$ & $47 \%$ & $45 \%$ & $45 \%$ & $44 \%$ & $45 \%$ & $46 \%$ \\
Hungary & $43 \%$ & $40 \%$ & $38 \%$ & $36 \%$ & $35 \%$ & $36 \%$ & $36 \%$ & $37 \%$ \\
India & $93 \%$ & $92 \%$ & $92 \%$ & $93 \%$ & $93 \%$ & $94 \%$ & $95 \%$ & $95 \%$ \\
Indonesia & $93 \%$ & $92 \%$ & $89 \%$ & $88 \%$ & $86 \%$ & $88 \%$ & $89 \%$ & $88 \%$ \\
Greece & $89 \%$ & $87 \%$ & $89 \%$ & $89 \%$ & $88 \%$ & $86 \%$ & $86 \%$ & $86 \%$ \\
Thailand & $98 \%$ & $99 \%$ & $97 \%$ & $96 \%$ & $96 \%$ & $96 \%$ & $97 \%$ & $97 \%$ \\
Turkey & $84 \%$ & $88 \%$ & $89 \%$ & $89 \%$ & $74 \%$ & $72 \%$ & $73 \%$ & $74 \%$ \\
Poland & $67 \%$ & $65 \%$ & $65 \%$ & $64 \%$ & $64 \%$ & $63 \%$ & $63 \%$ & $64 \%$ \\
Saudi Arabia & $90 \%$ & $97 \%$ & $95 \%$ & $95 \%$ & $92 \%$ & $92 \%$ & $91 \%$ & $91 \%$ \\
South Africa & $97 \%$ & $95 \%$ & $93 \%$ & $94 \%$ & $91 \%$ & $91 \%$ & $90 \%$ & $90 \%$
\end{tabular}

Table A2. Credit of Banking Sector to Total Financing in Developed Countries

\begin{tabular}{|c|c|c|c|c|c|c|c|c|}
\hline \multirow{2}{*}{ Country } & \multicolumn{8}{|c|}{ Year/Quarter } \\
\hline & 2011 & 2012 & 2013 & 2014 & 2015 & 2016 & Q1 17 & Q2 17 \\
\hline United Kingdom & $58 \%$ & $55 \%$ & $56 \%$ & $56 \%$ & $54 \%$ & $53 \%$ & $53 \%$ & $54 \%$ \\
\hline United States & $33 \%$ & $33 \%$ & $33 \%$ & $33 \%$ & $34 \%$ & $35 \%$ & $34 \%$ & $34 \%$ \\
\hline Canada & $51 \%$ & $53 \%$ & $53 \%$ & $52 \%$ & $51 \%$ & $52 \%$ & $52 \%$ & $51 \%$ \\
\hline Australia & $70 \%$ & $69 \%$ & $68 \%$ & $68 \%$ & $69 \%$ & $71 \%$ & $71 \%$ & $71 \%$ \\
\hline Austria & $64 \%$ & $63 \%$ & $61 \%$ & $59 \%$ & $59 \%$ & $59 \%$ & $58 \%$ & $59 \%$ \\
\hline Belgium & $27 \%$ & $26 \%$ & $27 \%$ & $28 \%$ & $29 \%$ & $29 \%$ & $29 \%$ & $29 \%$ \\
\hline Czech Republic & $59 \%$ & $58 \%$ & $56 \%$ & $56 \%$ & $55 \%$ & $58 \%$ & $58 \%$ & $58 \%$ \\
\hline Denmark & $72 \%$ & $72 \%$ & $74 \%$ & $74 \%$ & $75 \%$ & $77 \%$ & $78 \%$ & $78 \%$ \\
\hline Finland & $53 \%$ & $53 \%$ & $52 \%$ & $53 \%$ & $49 \%$ & $53 \%$ & $53 \%$ & $52 \%$ \\
\hline France & $54 \%$ & $53 \%$ & $53 \%$ & $51 \%$ & $50 \%$ & $50 \%$ & $50 \%$ & $50 \%$ \\
\hline Germany & $75 \%$ & $75 \%$ & $73 \%$ & $72 \%$ & $72 \%$ & $72 \%$ & $71 \%$ & $71 \%$ \\
\hline Italy & $75 \%$ & $72 \%$ & $71 \%$ & $71 \%$ & $73 \%$ & $72 \%$ & $72 \%$ & $72 \%$ \\
\hline Japan & $63 \%$ & $65 \%$ & $67 \%$ & $67 \%$ & $69 \%$ & $68 \%$ & $69 \%$ & $69 \%$ \\
\hline Korea & $71 \%$ & $69 \%$ & $67 \%$ & $67 \%$ & $67 \%$ & $68 \%$ & $69 \%$ & $69 \%$ \\
\hline Netherlands & $50 \%$ & $52 \%$ & $51 \%$ & $49 \%$ & $48 \%$ & $48 \%$ & $48 \%$ & $48 \%$ \\
\hline Norway & $35 \%$ & $33 \%$ & $33 \%$ & $33 \%$ & $31 \%$ & $32 \%$ & $32 \%$ & $32 \%$ \\
\hline
\end{tabular}


Avalaible online at http://journals.ums.ac.id, Permalink/DOI: 10.23917/jep.v19i2.5244

Jurnal Ekonomi Pembangunan: Kajian Masalah Ekonomi dan Pembangunan, 19 (2), 2018, 138-155

\begin{tabular}{ccccccccc}
\hline \multirow{2}{*}{ Country } & \multicolumn{7}{c}{ Year/Quarter } \\
\cline { 2 - 8 } & $\mathbf{2 0 1 1}$ & $\mathbf{2 0 1 2}$ & $\mathbf{2 0 1 3}$ & $\mathbf{2 0 1 4}$ & $\mathbf{2 0 1 5}$ & $\mathbf{2 0 1 6}$ & $\mathbf{Q 1 ~ 1 7}$ & $\mathbf{Q 2 ~ 1 7}$ \\
\hline Spain & $74 \%$ & $72 \%$ & $69 \%$ & $67 \%$ & $66 \%$ & $65 \%$ & $64 \%$ & $64 \%$ \\
Sweden & $56 \%$ & $57 \%$ & $57 \%$ & $56 \%$ & $55 \%$ & $56 \%$ & $56 \%$ & $57 \%$ \\
Switzerland & $76 \%$ & $77 \%$ & $77 \%$ & $77 \%$ & $79 \%$ & $79 \%$ & $79 \%$ & $79 \%$ \\
Luxembourg & $21 \%$ & $20 \%$ & $21 \%$ & $23 \%$ & $22 \%$ & $24 \%$ & $24 \%$ & $25 \%$ \\
Ireland & $36 \%$ & $36 \%$ & $35 \%$ & $29 \%$ & $16 \%$ & $16 \%$ & $17 \%$ & $18 \%$ \\
Portugal & $69 \%$ & $65 \%$ & $64 \%$ & $62 \%$ & $60 \%$ & $60 \%$ & $59 \%$ & $59 \%$ \\
Russia & $76 \%$ & $79 \%$ & $78 \%$ & $76 \%$ & $76 \%$ & $76 \%$ & $76 \%$ & $76 \%$ \\
average for developed & $57 \%$ & $56 \%$ & $56 \%$ & $55 \%$ & $55 \%$ & $55 \%$ & $55 \%$ & $55 \%$ \\
countries & & & & & & & &
\end{tabular}

Source: Bank for international settlement
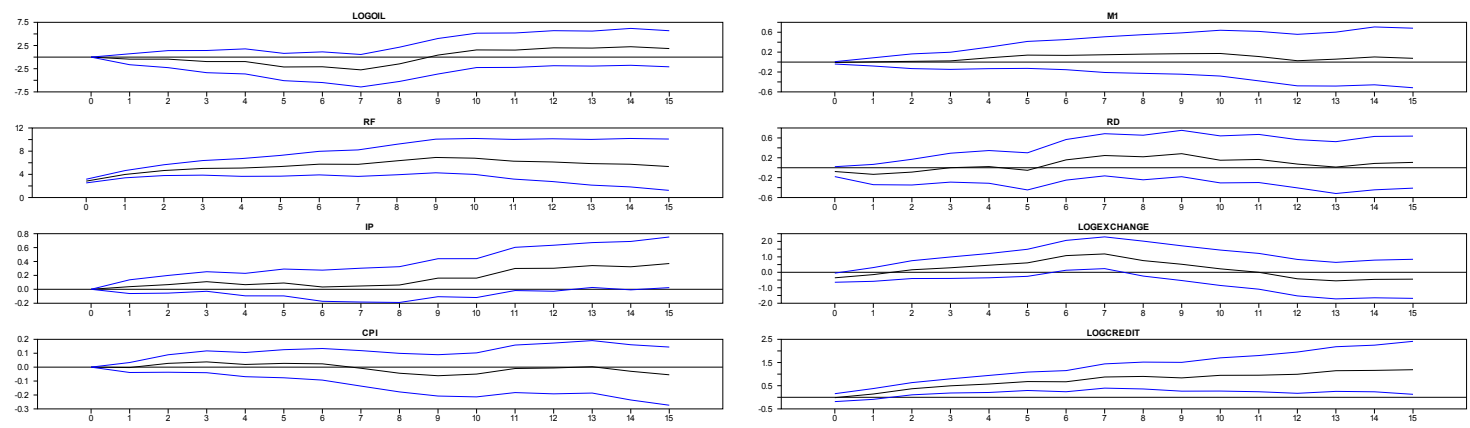

Responses to if

Source: RATS output

Figure 1. Response to foreign interest rate shocks for Mexico
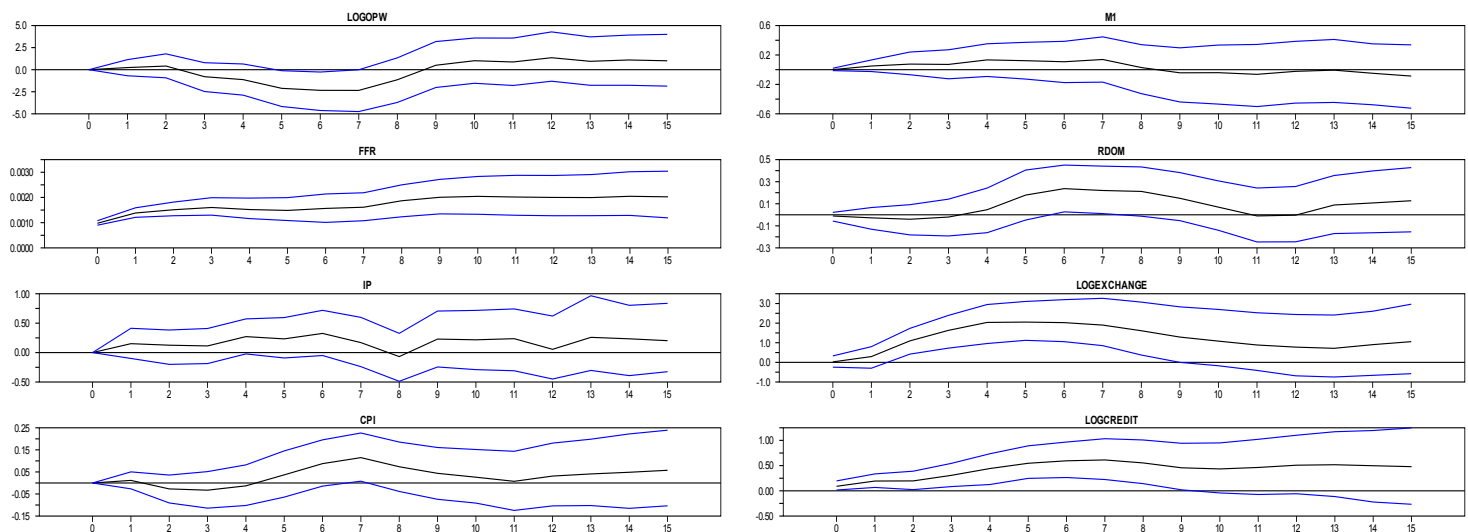

Responses to if

Source: RATS output

Figure 2. Response to foreign interest rate shocks for Colombia 

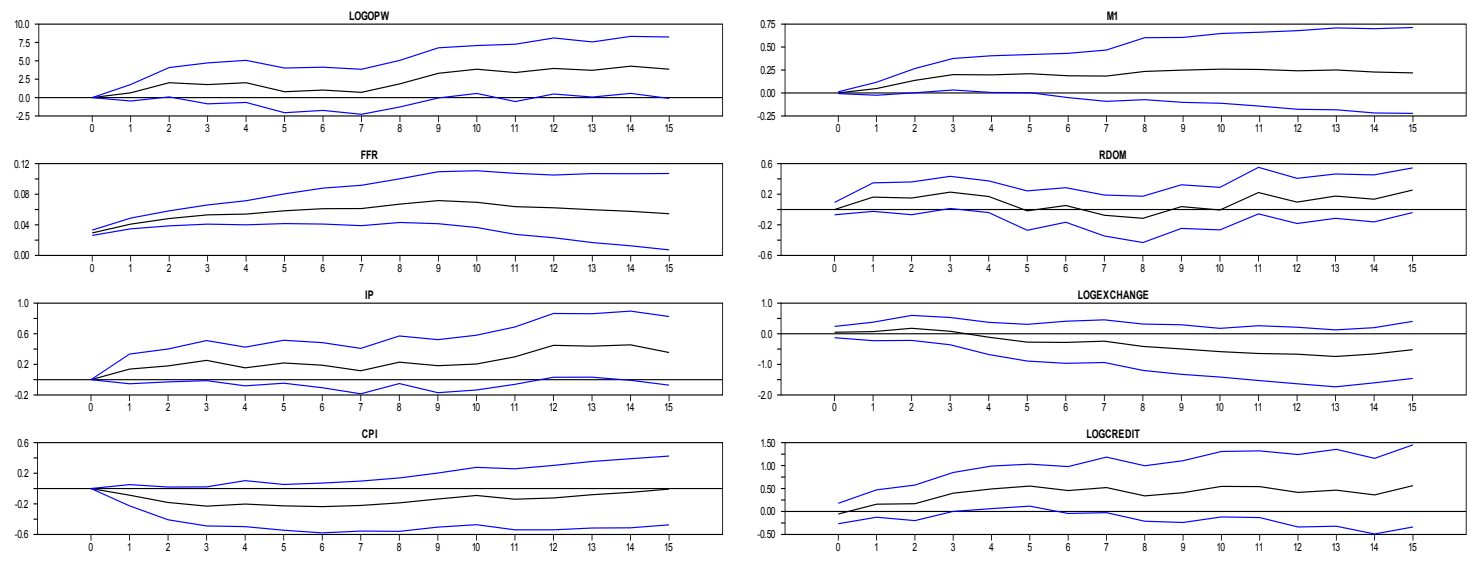

Responses to if

Source: RATS output

Figure 3. Response to foreign interest rate shocks for India
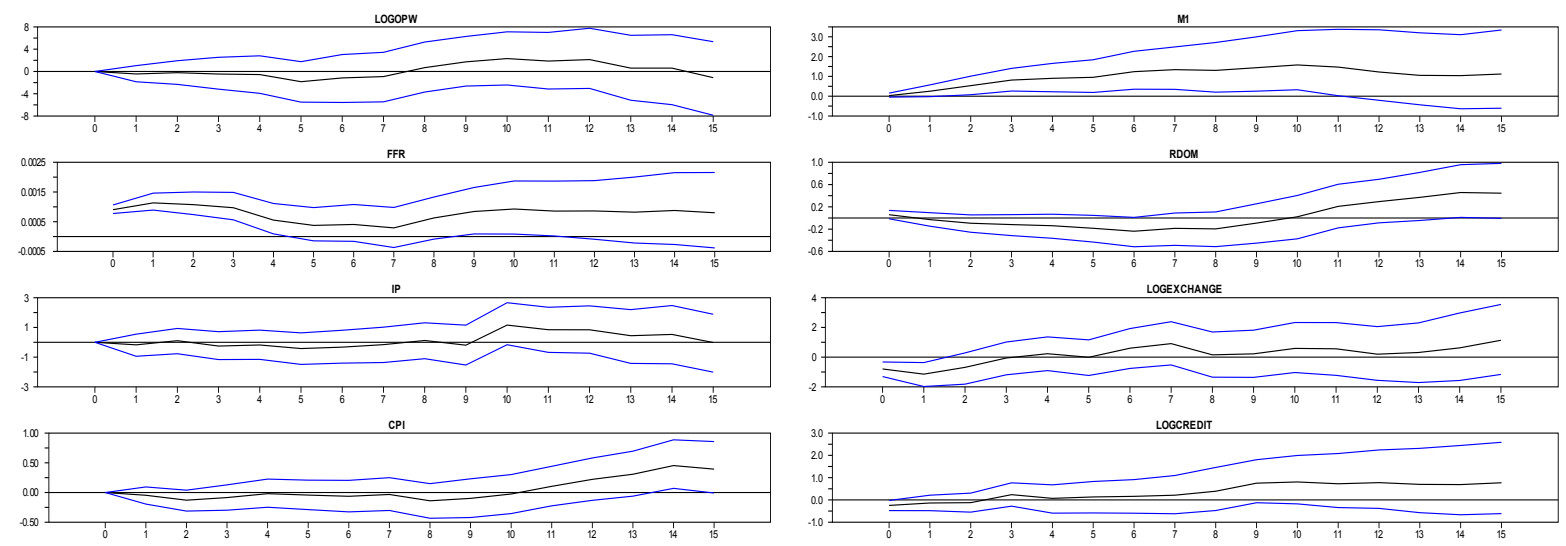

Responses to if

Source: RATS output

Figure 4. Response to foreign interest rate shocks for Turkey
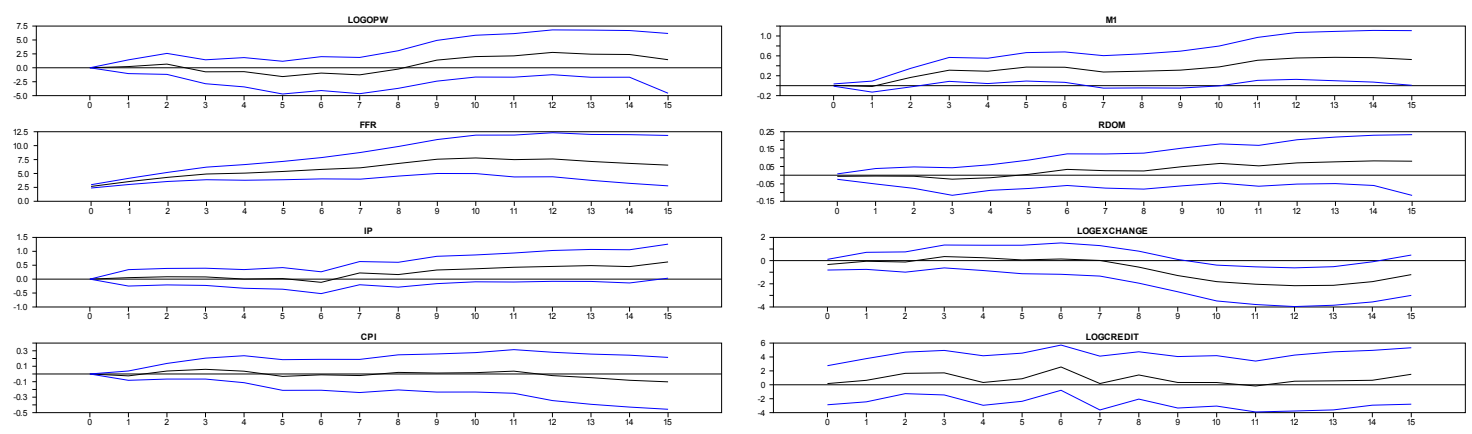

Responses to if

Source: RATS output

Figure 5. Response to foreign interest rate shocks for South Africa 

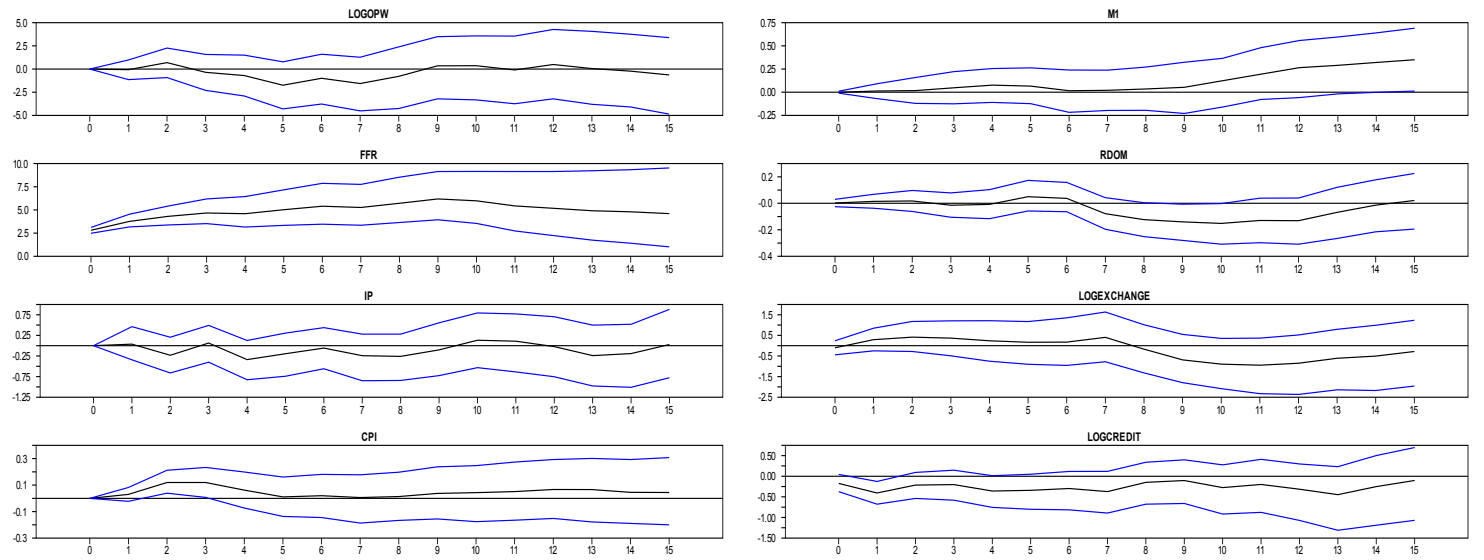

Responses to if

Source: RATS output

Figure 6. Response to foreign interest rate shocks for Chile
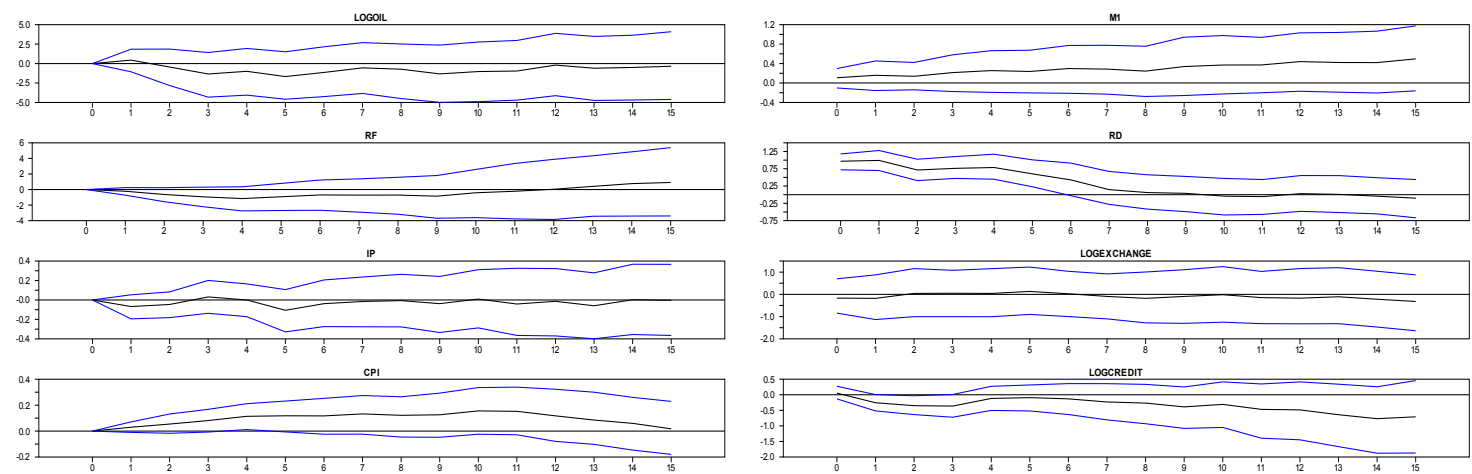

Responses to rd

Source: RATS output

Figure 7. Response to monetary policy shocks for Mexico
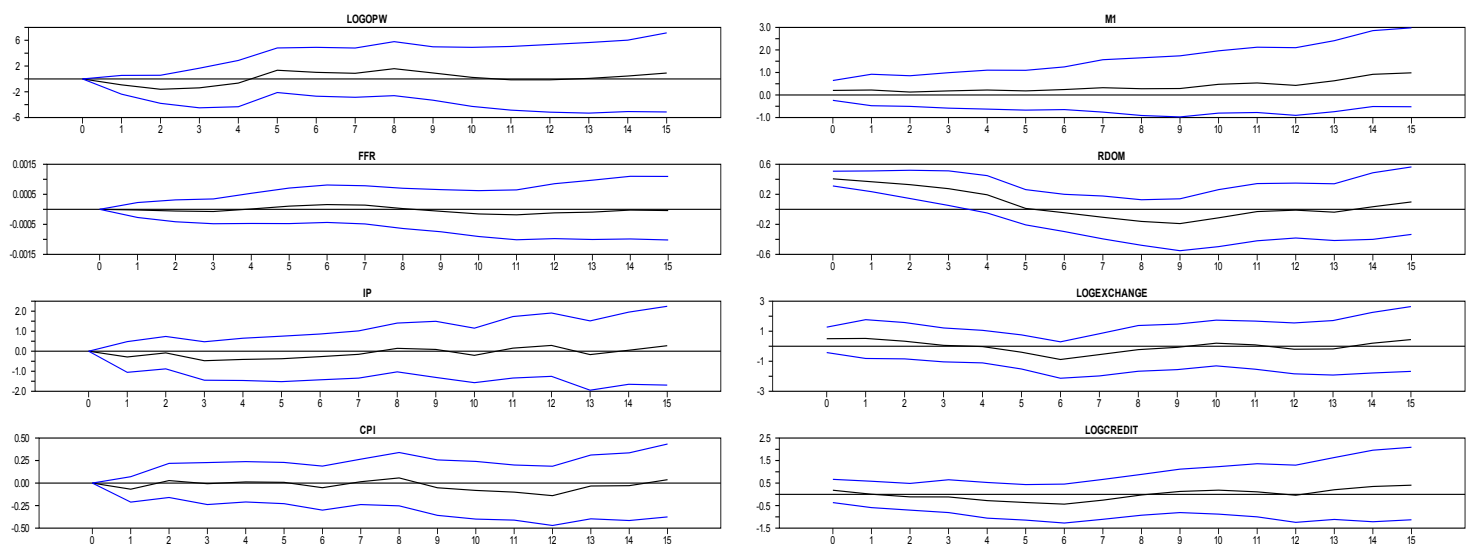

Responses to rd

Source: RATS output

Figure 8. Response to monetary policy shocks for Turkey 

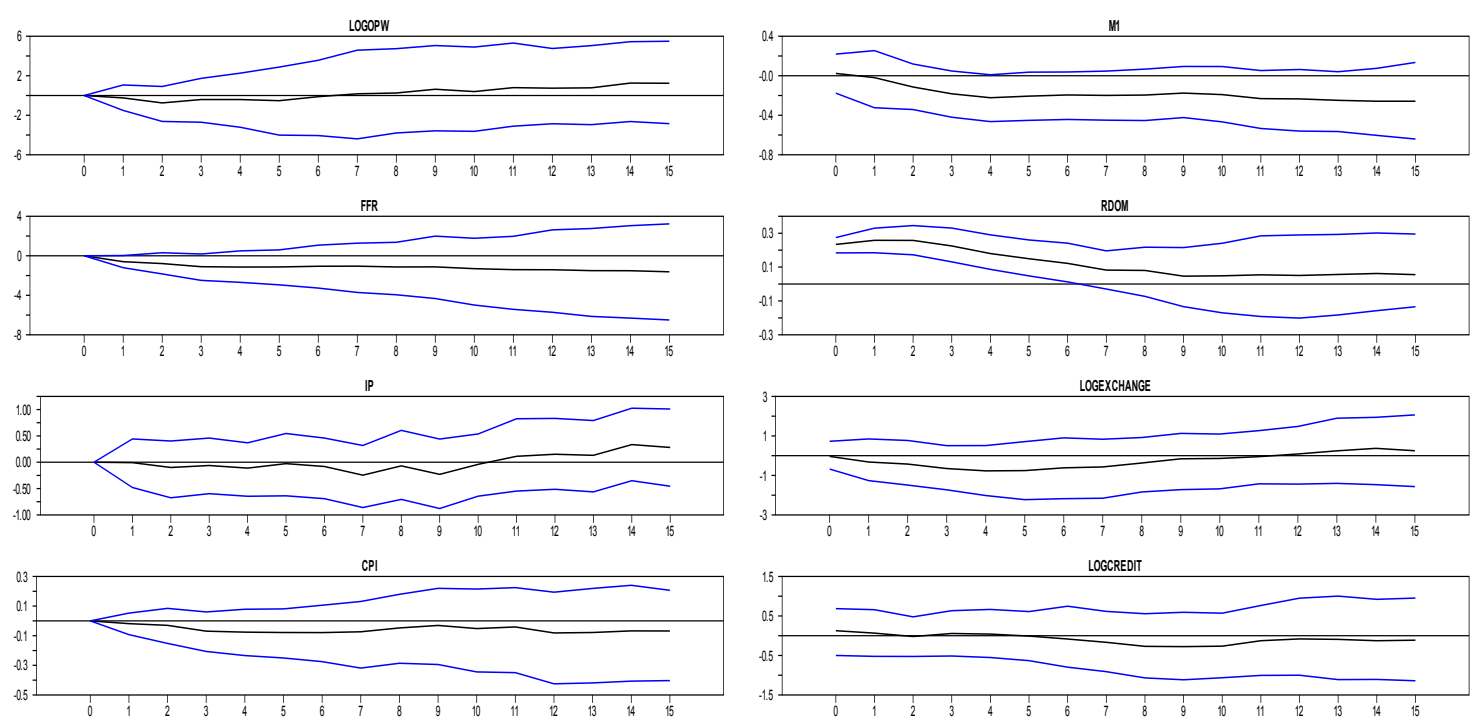

Responses to rd

Source: research results

Figure 9. Response to monetary policy shocks for Chile
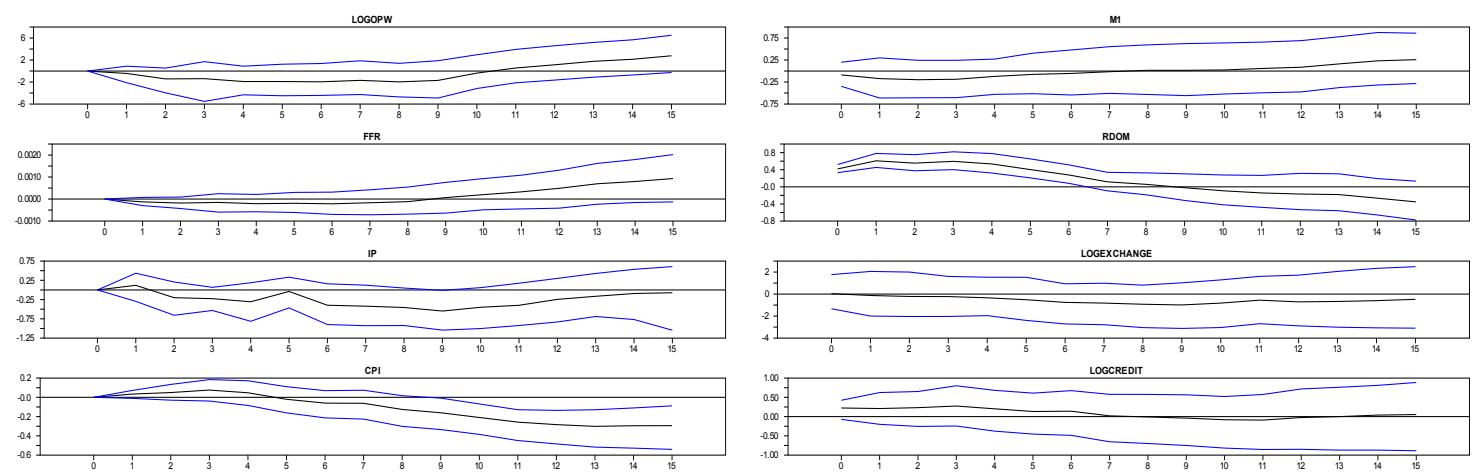

Responses to rd

Figure 10. Response to monetary policy shocks for Colombia 
Avalaible online at http://journals.ums.ac.id, Permalink/DOI: 10.23917/jep.v19i2.5244

Jurnal Ekonomi Pembangunan: Kajian Masalah Ekonomi dan Pembangunan, 19 (2), 2018, 138-155
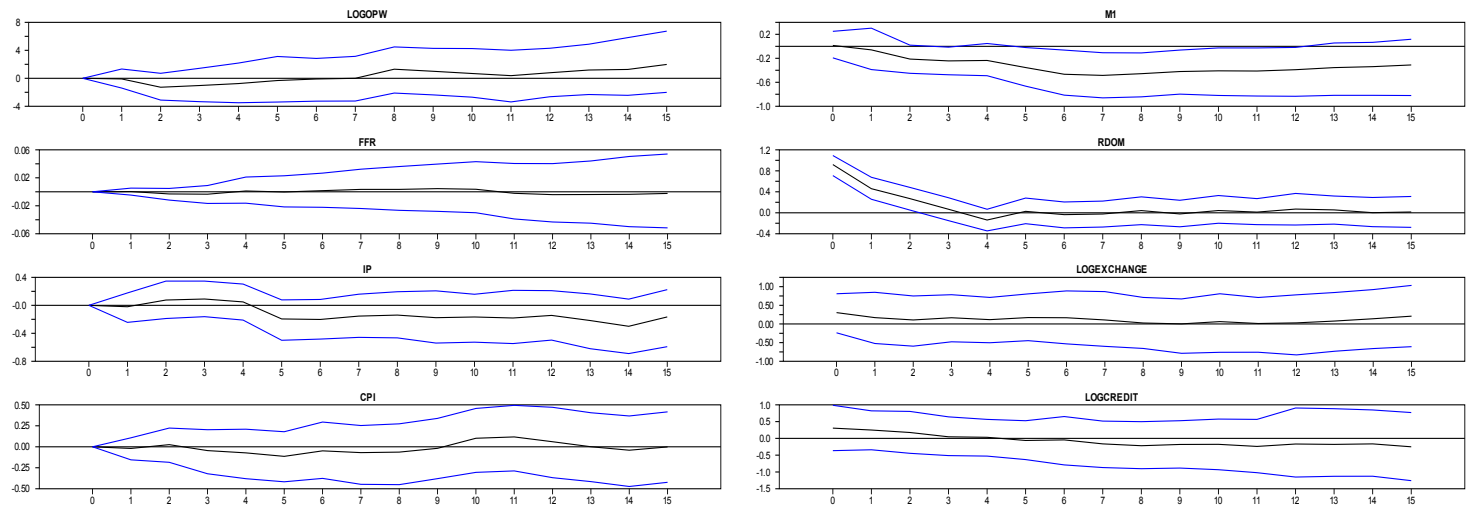

Responses to rd

Figure 11. Response to monetary policy shocks for India

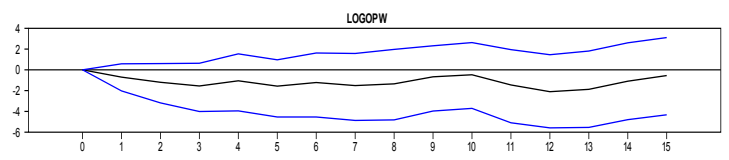

FFR
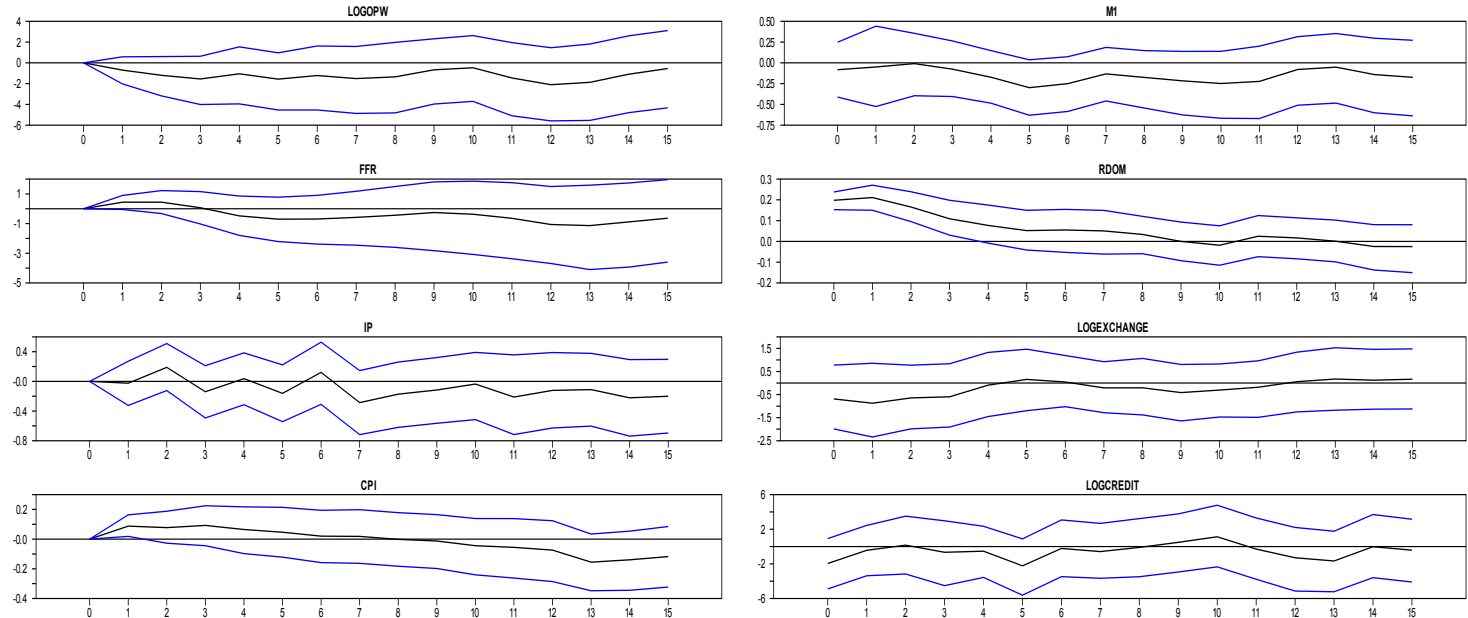

RDOM
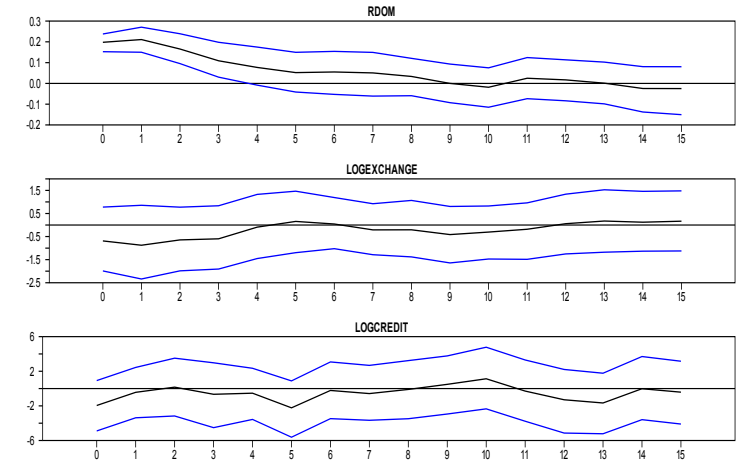

Responses to rd

Figure 12. Response to monetary policy shocks for South Africa 